FIU Law Review

Fall 2012

\title{
Closing the Floodgates: The Battle Over Workers' Compensation Rights in California
}

\author{
Gabe Feldman \\ Tulane Law School
}

Follow this and additional works at: https://ecollections.law.fiu.edu/lawreview

Part of the Other Law Commons

Online ISSN: 2643-7759

\section{Recommended Citation}

Gabe Feldman, Closing the Floodgates: The Battle Over Workers' Compensation Rights in California, 8 FIU L. Rev. 107 (2012).

DOI: https://dx.doi.org/10.25148/lawrev.8.1.11

This Article is brought to you for free and open access by eCollections. It has been accepted for inclusion in FIU Law Review by an authorized editor of eCollections. For more information, please contact lisdavis@fiu.edu. 


\title{
Closing the Floodgates: The Battle Over Workers' Compensation Rights in California
}

\author{
Gabe Feldman*
}

\section{INTRODUCTION}

The concussion lawsuits facing the National Football League (NFL) have been heralded as the "tobacco litigation" of the NFL and garnered panicked reports of the demise of our modern-day national pastime. Merits of the case aside, the sheer number of plaintiffs suing the league is staggering. As of November 1, 2012, 3,798 former players-encompassing 170 lawsuits-had filed concussion-related lawsuits against the NFL. ${ }^{1}$ In other words, more than $30 \%$ of all living retired NFL players are suing the NFL for injuries related to concussions and head trauma. The lawsuits allege that the NFL failed to take reasonable steps to protect players from the risks ${ }^{2}$-including neurocognitive decline, permanent mental disability, and death — created by concussive and sub-concussive head injuries suffered while playing in NFL games. The plaintiffs also allege that the NFL not only breached its duty to prevent harm to its players, but also "orchestrated a campaign of disinformation designed to convince [p]layers ... that concussive and sub-concussive blows posed no real danger." ${ }^{3}$

\footnotetext{
* Associate Professor, Tulane Law School; Director, Tulane Sports Law Program; Associate Provost for NCAA Compliance, Tulane University.

1 See Paul D. Anderson, Plaintiffs/Former Players, NFL CONCUSSION LITIGATION (Nov. 1, 2012), http://nflconcussionlitigation.com/?page_id=274.

2 See Plaintiffs' Amended Master Administrative Long-Form Complaint, II II 72-74, 133, 238, In re National Football League Players' Concussion Injury Litigation, No. 2:12-md-02323AB (E.D. Pa. July 17, 2012), MDL No. 2323 [hereinafter Long-Form Complaint]. The Master Complaint further alleges that "players who sustain repeated concussive and sub-concussive impacts are at great risk of developing chronic traumatic encephalopathy and other serious neurological disorders. . . [and] [t]hose disorders, which remain latent for years, can culminate in severe disability and death." See Memorandum of Plaintiffs in Opposition to Defendants National Football League's And NFL Properties LLC's Motion to Dismiss the Amended Master Administrative Long-Form Complaint at 4, In re National Football League Players' Concussion Injury Litigation, No. 2:12-md-02323-AB (E.D. Pa. Oct. 31, 2012), MDL No. 2323 [hereinafter Memorandum in Opposition].

3 Memorandum in Opposition, supra note 2, at 6. The players allege that the NFL formed the Mild Traumatic Brain Injury (MTBI) Committee in 1994 to:
} 
While the massive multi-district concussion litigation has stolen the headlines as the case winds its way through the courts, former players and teams are (relatively quietly) battling over the players' ability to collect workers' compensation benefits for similar injuries. In particular, the players and owners are fighting over the players' access to California's flexible workers' compensation regime despite the fact that many of these players are long-retired and/or did not play for one of the NFL's California-based teams.

The workers' compensation floodgates opened with a wave of claims brought in California ${ }^{5}$ by former NFL players who suffered a variety of orthopedic injuries. More than 700 former players brought such claims with the typical lump-sum settlement amounting to between $\$ 100,000$ and $\$ 200,000{ }^{6}$ Notably, most of these players would have been ineligible to file for workers' compensation claims in any other state. The second wave, however, has featured claims by players who suffered head trauma while playing in the NFL. Typically, these claims have settled in the six figure range, including an agreed-upon indemnity and obligation to cover future medical care.

create a façade of scientific research that the NFL could invoke to conceal the fact that the game it oversaw - and from which it reaped billions of dollars - was slowly ruining the lives of many players. To accomplish that deceit, the MTBI Committee performed several studies, purporting to find no link between football-related head trauma and long-term brain damage.

Id. at 7. The Master Complaint also claims that the MTBI Committee's findings were "a sham" and that Dr. Elliot Pellman, the head of the committee, "was unqualified and served as a mere mouthpiece for the NFL's political agenda." Id.; see also id. (alleging that the MTBI Committee "conducted severely flawed studies, fired scientists who dissented from its faulty conclusions, and actively disputed other studies that revealed the truth").

4 The NFL has moved to dismiss the entirety of the Master Complaint on the grounds that all of the claims are preempted by the terms of the Collective Bargaining Agreement under $\S$ 301 of the Labor Management Relations Act (LMRA) and 29 U.S.C. $\$ 185$ (1947). See generally Memorandum of Law of Defendants National Football League and NFL Properties LLC in Support of Motion to Dismiss the Amended Master Administrative Long-Form Complaint on Preemption Grounds, In re National Football League Players' Concussion Injury Litigation, No. 2:12-md-02323-AB (E.D. Pa. Aug. 30, 2012). The parties are scheduled to finish briefing the preemption issue by the end of 2012 and the court will consider the preemption argument as a threshold issue separate and apart (and before) considering the NFL's other arguments on its motion to dismiss.

5 These cases do not present any meaningful financial cost to California because most of the claims are paid by the teams or their insurance carriers or a state fund that is underwritten by businesses already paying for workers' compensation insurance. Alan Schwarz, Case Will Test N.F.L. Teams' Liability in Dementia, N.Y. TIMES, Apr. 6, 2010, at A1, available at http://www.nytimes.com/2010/04/06/sports/football/06worker.html?pagewanted=all\&_r=0.

6 Id.

$7 \quad$ Id.

8 Presentation by Jason Hillman, Vice President and Gen. Counsel, Cavaliers Operating Co., in Las Vegas, Nev. at the Am. Bar Ass'n Forum on the Sports and Entm't Indus. Conference (Oct. 4-6, 2012). 
Given the over 4,000 plaintiffs who have sued the NFL for concussion-related claims, there are likely hundreds of players who may be able to seek workers' compensation claims in California for head trauma. Although the possible exposure from these claims is speculative, the risk is significant and could cost NFL teams and their insurers in excess of $\$ 100$ million. $^{10}$ At a minimum, the annual impact on teams is no longer a blip on the balance sheet. Insurance premiums for California are rising at a rapid clip, and it is not unheard of for an NFL team to be paying in excess of $\$ 1$ million per year in premiums in California alone. These claims also have the potential to impact nonsport team employers-anyone who has employees working or even attending conferences in California-and could force some employers to limit or eliminate their employees' work in California. ${ }^{12}$

The NFL and its teams are trying to shut the door on this "Gold Rush" by contracting around California law in the standard player contract with choice of law or choice of forum provisions and by utilizing California's "reciprocity measure" to limit the players' claims to the home state of their former NFL teams. Each of these arguments-and the reason for the workers' compensation "Gold Rush" in California-will be discussed in this short essay.

\section{CALIFORNIA'S WORKERS' COMPENSATION REGIME OPENED THE FLOODGATES FOR CLAIMS FROM RETIRED NFL PLAYERS}

Workers' compensation laws provide protections and benefits for employees who are injured in the course of their employment. In the typical case, the workers' compensation regime grants tort immunity to employers in exchange for the regime's protections and benefits to the employee. Although some states have specifically excluded professional athletes from workers' compensation coverage, ${ }^{13}$ most states'

\section{See Anderson, supra note 1.}

10 Hillman, supra note 8.

11 Id.

12 In fact, the Arena Football League has chosen not to field a team in California to avoid the exposure to the state's workers' compensation regime. Schwarz, supra note 5.

13 See FlA. STAT. § 440.02 (2012) (excluding “[p]rofessional athletes, such as professional boxers, wrestlers, baseball, football, basketball, hockey, polo, tennis, jai alai, and similar players"); 77 PA. CONS. StAT. § 565 (2012); TEX. LAB. CODE § 406.095 (2005) ("A professional athlete employed under a contract for hire or a collective bargaining agreement who is entitled to benefits for medical care and weekly benefits that are equal to or greater than the benefits provided under this subtitle may not receive benefits under this subtitle and the equivalent benefits under the contract or collective bargaining agreement. An athlete covered by such a contract or agreement who sustains an injury in the course and scope of the athlete's employment shall elect to receive either the benefits available under this subtitle or the benefits under the contract or agreement."). 
regimes treat professional athletes and their teams like any other employee-employer relationship.

California's workers' compensation laws have invited a flood of claims from former NFL players ${ }^{15}$ because of a multitude of playerfriendly components of California law.

First, California is virtually alone among the states home to NFL teams that recognizes "cumulative injury" as a basis for recovery of workers' compensation. "As opposed to a "specific" injury, which is caused by one incident or exposure, "cumulative" injury can be the result of "repetitive mentally or physically traumatic activities extending over a period of time, the combined effect of which causes any disability or need for medical treatment." ${ }^{17}$ Retired NFL players have thus been able to receive compensation for head, neck, and neurological injuries.

Second, California has an employee-friendly statute of limitations that is tolled until the employer formally notifies the employee of his rights under California's workers' compensation system..$^{18}$ NFL teams, either believing that they had adequately taken care of their players' medical conditions at the time, or hoping to avoid workers' compensation claims, or simply being unaware of the possibility of such claims, historically had not informed their players of their rights under Cali-

14 In a case involving a former major league baseball player, the player argued that workers' compensation does not apply to "high price athletes." The court rejected the argument, holding that workers' compensation applies to "all employees regardless of their earnings. If professional athletes were excluded from coverage, then hundreds and possibly thousands of low as well as high priced athletes on Major and Minor League Teams would be deprived of the humanitarian benefits and protection the Act affords." Bayless v. Philadelphia Nat'l League Club, 472 F. Supp. 625, 631 (E.D. Pa. 1979).

15 Former players in other professional sports leagues, including the National Basketball Association, have brought claims in California, but this brief essay will focus on the NFL-related claims and litigation.

16 See Cal. Lab. Code $\$ 3208.1$ (2010); see also Bobbie N. Roquemore, Creating a Level Playing Field: The Case for Bringing Workers' Compensation for Professional Athletes into a Single Federal System by Extending the Longshore Act, 57 LOY. L. REV. 793, 826-28 (2011).

17 See CAL. LAB. CODE $\S 3208.1$ (2010).

18 See CAL. LABOR CODE $\S 3550$ (2012) (requiring employers to post in a conspicuous place the name of their insurance carrier and the entity responsible for workers compensation claims); see, e.g., Kaiser Found. Hosp. v. Workers' Comp. Appeals Bd., 702 P.2d 197, 201 (1985) ("[W]hen an employer fails to perform its statutory duty to notify an injured employee of his workers' compensation rights, the injured employee is unaware of those rights from the date of injury through the date of the employer's breach, then the statute of limitations will be tolled until the employee receives actual knowledge that he may be entitled to benefits under the workers' compensation system."). In contrast, most states have a one to five year statute of limitations on workers' compensation claims. See Schwarz, supra note 5. 
fornia's regime. This, in turn, tolled the statute and allowed NFL players from as early as the 1960's and 1970's to bring claims.

Third, California's system has a broad reach that covers employees of non-California employers who are injured while in California temporarily on behalf of their employers. Under Section 3600.5 of the California Labor Code, workers' compensation benefits in California are afforded to any employee who has been "hired or is regularly employed in the state and receives personal injury by accident arising out of and in the course of such employment outside of th[e] state."

The California Workers' Compensation Board has taken a wide view of the phrase "regularly employed" that has allowed NFL players to be covered under the broad umbrella of workers' compensation rights in the state. For example, in Injured Workers' Insurance Fund of Maryland v. Workers' Compensation Appeals Board (Crosby), a retired Baltimore Colts player was deemed to be regularly employed in California-and thus entitled to worker's compensation benefits in the state-despite the fact that he had only played a single game in California. ${ }^{21}$ Similarly, in Carroll v. Saints, a retired player for the Cincinnati Bengals and New Orleans Saints was found to be "regularly employed" in California despite the fact that he had only played two games in California during his four-year NFL career. ${ }^{22}$ Neither of these players were residents nor had they signed their employment contracts in California. ${ }^{23}$ Yet, in each case, this sporadic and infrequent time spent in California was deemed regular employment sufficient to entitle these NFL players to workers' compensation benefits in California.

Leroy Thompson's case serves as a good illustration. Thompson, a back-up running back, played in the NFL from 1991-1996 for the Pittsburgh Steelers, New England Patriots, Kansas City Chiefs, and Tampa Bay Buccaneers. ${ }^{24}$ He qualified for workers' compensation benefits in California because four of his eighty games were played in

19 Schwarz, supra note 5. For example, Lance Alworth, a wide receiver for the San Diego Chargers who retired in 1972 and is more than 70 years old, was able to bring a claim for workers' compensation benefits in 2010. Id.

20 CAL. LAB. CODE $§ 3600.5$ (2012).

21 See Injured Workers' Ins. Fund of Md. v. Workers' Comp. Appeals Bd., 29 Cal. Workers' Comp. Rep. 182 (2001). Similarly, in Rocor Transportation v. Workers' Compensation Appeals Board, the Board held that a long haul truck driver who spent less than ten percent of his employment in California was "regularly employed" within California and thus entitled to workers' compensation benefits in the state. 66 Cal. Cogeneration Council 1136 (2001).

22 Carroll v. New Orleans Saints, No. ADJ2295331 (ANA0397551) (Workers' Comp. Appeals Bd. Jan. 24, 2011). The Bengals, however, argued that he should be denied benefits because of Section 3600.5(b). See id. at 11.

$23 \quad I d$. at 12.

24 Schwarz, supra note 5. 
the state. His workers' compensation claim was filed in 2008 and alleged cumulative injuries to his "head, neck, back, spine, shoulder, hips, elbows, wrists, hands, legs, knees, ankles, [and] feet." ${ }^{25} \mathrm{He}$ received a settlement of $\$ 120,000$. $^{26}$

Attempts to limit the statutory availability of workers' compensation benefits to professional athletes in California have failed. In 1997, legislation-sponsored by NFL owners-was introduced that would have limited California worker's compensation benefits to athletes who lived in the state and would have prevented athletes from collecting benefits for cumulative injuries. This legislation, along with a bill that would have completely eliminated workers' compensation benefits for any professional athlete making more than $\$ 226,000$ a year, failed. ${ }^{27}$

As a result of California's unique workers' compensation regime, most major professional sports teams have faced claims in California filed by former players. ${ }^{28}$ This essay will focus on two approaches taken by NFL teams for limiting the workers' compensation rush to California-contracting around California through choice of law and choice of forum clauses and a statutory exclusion in California's workers' compensation system.

\section{CONTRACTING AROUND}

In response to the flood of claims filed in California, several NFL teams have inserted choice of law and/or choice of forum clauses in the standard player contract requiring players to file their workers' compensation claims in their home team's state and under their home team's law. ${ }^{29}$ Despite the contractual limitation, many former players pursued their claims in California, setting off a series of legal battles pitting the players versus their former teams and the contractual limitations versus California's statutory employee protections. These battles have all proceeded on a similar trajectory: 1) teams have filed for

25 Id.

26 Id.

27 See NFL Tackles Benefits, L.A. TIMES (Apr. 11, 1997), http://articles.latimes.com/199704-11/business/fi-47559_1_compensation-benefits.

28 See, e.g., Schwarz, supra note 5.

29 For example, Paragraph 26D of Bruce Matthews' contract with the Tennessee Titans provided as follows:

Jurisdiction of all workers compensation claims and all other matters related to workers compensation, including but not limited to the matters recited in Paragraph 10 hereof, and including all issues of law, issues of fact, and matters related to workers compensation benefits, shall be exclusively determined by and exclusively decided in accordance with the internal laws of the State of Tennessee without resort to choice of law rules.

See Matthews v. Nat'l Football League Mgmt. Council, 688 F.3d 1107, 1110 n.1 (9th Cir. 2012). 
arbitration to prevent the players from seeking workers' compensation benefits in California; 2) arbitrators have enforced the contractual limitations and ruled that the players may not seek benefits in California; 3) the teams have sought to confirm the awards (or the players have sought to overturn the award) in federal district court. ${ }^{30}$

In each of the cases, arbitrators ruled that the choice of law/forum provisions were enforceable and that the players had therefore breached their contracts by filing workers' compensation claims in California. In other words, the arbitrators ruled that an employee's workers' compensation rights are waivable and that the players had waived their rights by agreeing to choice of law/forum provisions in their player contracts.

The battle then shifted to federal court, where the NFL Players Association (NFLPA) has argued that the choice of law/choice of forum provisions are illegal and unenforceable because, inter alia, they deprive the former players of their statutory rights to workers' compensation benefits in California and are thus contrary to public policy. ${ }^{32}$ The NFLPA argues that California law-like virtually every other state law-renders workers' compensation benefits and protections unwaivable and declares void and unenforceable any contract attempting to waive California workers' compensation rights and protections. ${ }^{33}$ Without such protections for employees, the NFLPA contends employers would simply require employees to waive their

30 The seminal case involves NFL Hall of Famer Bruce Matthews and the Tennessee Titans. See Nat'l Football League Players Ass'n v. Nat'l Football League Mgmt. Council, No. 10CV1671 JLS WMC, 2011 WL 31068 (S.D. Cal. Jan. 5, 2011). Other cases that have involved former players include Chicago Bears Football Club, Inc. v. Haynes, 816 F. Supp. 2 d 534 (N.D. Ill. 2011), New Orleans Saints, LLC v. Cleeland, No. 2:11-cv-02093-KDE-ALC (E.D. La. Aug. 24, 2011) (Beck, Arb.); Kansas City Chiefs Football Club, Inc. v. Allen, No. 4:12-cv-00238-BCW (W.D. Mo. Feb. 24, 2012) (Beck, Arb.)., and Atlanta Falcons Football Club LLC v. Nat'l Football League Players Ass'n, No. 1:12-cv-00753-TWT (N.D. Ga. Feb. 23, 2012) (Beck, Arb.). These cases are virtually identical but for the fact that Matthews only involved a choice of law clause while the other players had choice of law and choice of forum provisions in their contracts.

31 See Williams v. Jacksonville Jaguars, No. ADJ7672393 (Cal. Workers' Comp. Appeals Bd. Aug. 9, 2012) (concluding that choice of law/forum provision in player contract required player to seek workers' compensation claim in the chosen state instead of California); Carroll v. New Orleans Saints, No. ADJ2295331 (ANA0397551) (Workers' Comp. Appeals Bd. Jan. 24, 2011).

32 Specifically, the players argue that the contractual limitation violates California public policy, federal law, and the Full Faith and Credit Clause. This essay will focus on the public policy aspect of the issue.

33 See CAL. LAB. CODE $\S 5000$ (2012) ("No contract, rule, or regulation shall exempt the employer from liability for the compensation fixed by this division"); see also id. § 2804 ("Any contract or agreement, express or implied, made by any employee to waive the benefits of this article or any part thereof, is null and void, and this article shall not deprive any employee or his personal representative of any right or remedy to which he is entitled under the laws of this State"). 
workers' compensation rights thus nullifying the important protections provided by the workers' compensation regime.

Courts have recognized the supremacy of California workers' compensation rights in the past. The key precedent in the area is Alaska Packers' Association v. Industrial Accident Commission of California, a case that worked its way through the California ${ }^{34}$ and United States $^{35}$ Supreme Courts. ${ }^{36}$ In Alaska Packers', an employment agreement contained a choice of law provision which provided that workers' compensation disputes would be handled under Alaska law. ${ }^{37}$ Despite this provision, the employee applied for workers' compensation benefits under California law. ${ }^{38}$ The California Supreme Court concluded that the choice of law clause was void under California law, holding that a "contract attempting to avoid the liability imposed by the California [workers' compensation] Act is invalid." States Supreme Court reached a similar conclusion holding that California had a legitimate state interest in protecting the rights of its employees and did not exceed its power by precluding the waiver of workers' compensation rights to achieve that end. ${ }^{41}$ As Professor Lar-

34 Alaska Packers' Ass'n v. Indus. Accident Comm'n of Cal., 34 P.2d 716 (1934). See also 22 Ops. Cal. Att'y Gen. 205 (Dec. 4, 1953) ("In the case of an attempted waiver of workmen's compensation benefits, any such agreement is not only obviously against public policy, but is specifically prohibited by statute. It might be noted in passing that in private employment any agreements to waive employees' rights against their employer for injury or death, etc., are void, as against public policy.”).

35294 U.S. 532 (1935).

36 The NFLPA also relies on Bowen v. Workers' Compensation Appeals Board., where the court held that a contract clause attempting to defeat an employee's claim for workers' compensation "would violate section 5000 prohibiting contracts exempting employers from liability under California Workers' Compensation Act." 73 Cal. App. 4th Supp. 15, 26-27 (Cal. Dist. Ct. App. 1999). See also Booker v. Cincinnati Bengals, Inc., No. ANA0401410, slip op. at 16 (Cal. Workers' Comp. App. Bd. 2009) ("Any provision of the employment agreement between Mr. Booker and the Bengals which purports to limit the applicant's ability to pursue workers' compensation benefits in the state of California is void and unenforceable.").

37 See Alaska Packers' Ass'n v. Indus. Accident Comm'n of Cal., 294 U.S. 532, 538 (1935).

38 Id. at 538-39.

39 Under the predecessor statute to California Labor Code Section 5000.

40 Alaska Packers' Ass'n, 34 P.2d at 721.

41 Alaska Packers' Ass'n, 294 U.S. 532. Other courts have similarly concluded that NFL players cannot contractually waive their rights to seek workers' compensation benefits in those states. See, e.g., Pro-Football, Inc. v. Tupa, 14 A.3d 678, 685 (Md. Ct. Spec. App. 2011) (“[T]he very purpose of [the anti-waiver provision in the workers' compensation statute] is to ensure that employers cannot contract out of coverage."); Miami Dolphins, Ltd. v. Newson, 783 F. Supp. 2d 769, 773-74 (W.D. Pa. 2011) (discussing the workers' compensation claim that rejected the Dolphins' attempt to contractually limit former players' ability to seek workers' compensation benefits in Pennsylvania); Bowen v. Workers' Comp. Appeals Bd., 73 Cal.App.4th 15, $26-27$ (1999) (prohibiting waiver of California's workers' compensation benefits where contract was formed in California and employee was resident of California); Nat'l Football League Players Ass'n v. ProFootball, 857 F. Supp. 71, 76-77, 80 (D.D.C. 1994) (vacating a NFL arbitration award because it violated a state's public policy as codified by state statute). See also P.I. \& I. Motor Express, Inc. 
son has explained, the rationale for preventing the contractual waiver of workers' compensation rights is that such "compensation is not a private matter to be arranged between two parties; the public has a profound interest in the matter which cannot be altered by any agreements." ${ }^{42}$

Despite the holding in Alaska Packers', all of the players' attempts to date to override the contractual limitations in their contracts have been rebuffed. ${ }^{43}$ The basic rationale for choosing the contractual limitation over the statutory workers' compensation rights has been consistent in all of the cases-the players simply did not have sufficient contacts with California to fall clearly within the ambit of California's workers' compensation regime. That is, with limited exception, none of the players alleged that they actually sustained any particular injury while playing in California, and none of the players signed their contracts in California or played a significant number of games in California. Rather, the players signed their contracts in their teams' home states, played the significant majority of their games (and practices) outside of California, and only alleged that they had suffered cumulative injuries either at "various locations," "various locations and practice facilities," or "various cities and states."

A key point in analyzing these cases is to recognize that the courts were not permitted to review the arbitrators' decisions de novo. Rather, the courts could only vacate the arbitration awards on public policy grounds if "an explicit, well defined and dominant public policy exists ... and the policy is one that specifically militates against the relief ordered by the arbitrator," and such "public policy must be

v. Indus. Comm'n, 857 N.E.2d 784, 790 (Ill. App. Ct. 2006) (“[A]ny agreement between an employer and an employee which purports to divest the Commission of jurisdiction where it otherwise exists is contrary to the public policy of this State and is, therefore, unenforceable."); Swenson v. Nickaboine, 793 N.W.2d 738, 743 (Minn. 2011); Gotkin v. Weinberg, 66 A.2d 438, 439 (N.J. 1949); McIlvaine Trucking, Inc. v. Workers' Comp. Appeals Bd., 810 A.2d 1280, 1286 (Pa. 2002); Jenkins v. Sal Chem. Co., 280 S.E.2d 243, 244 (W. Va. 1981).

429 LEX K. LARSON, LARSON's WORKERS' COMPENSATION LAW § 143.07 (Matthew Bender, Rev. Ed. 2010).

43 See infra note 45.

44 One former player for the Atlanta Falcons did allege that he suffered an injury in California. See Atlanta Falcons Football Club LLC v. Nat'l Football League Players Ass'n, No. 1:12cv-00753-TWT (N.D. Ga. Feb. 23, 2012) (Beck, Arb.).

45 See Matthews v. Nat'l Football League Mgmt. Council, 688 F.3d 1107, 1110, 1113 (9th Cir. 2012); New Orleans Saints, LLC v. Cleeland, No. 2:11-cv-02093-KDE-ALC (E.D. La. Aug. 24, 2011) (Beck, Arb.); Atlanta Falcons Football Club LLC v. Nat'l Football League Players Ass'n, No. 1:12-cv-00753-TWT (N.D. Ga. Feb.23, 2012) (Beck, Arb.).

46 United Food \& Commercial Workers' Int'l Union, Local 588 v. Foster Poultry Farms, 74 F.3d 169, 174 (9th Cir. 1995) (internal quotation marks omitted). See Foster Poultry Farms, 74 F.3d at 173 ("[B]ecause federal labor policy strongly favors the resolution of labor disputes through arbitration, [j]udicial scrutiny of an arbitrator's decision is extremely limited.") (internal 
ascertained by reference to the laws and legal precedents and not from general considerations of supposed public interests." ${ }^{47}$

The heavy burden of overturning an arbitration decision on public policy grounds helped doom the players' cases. Matthews, the only case to produce a federal appellate decision to date, is instructive. In Matthews, the district court rejected the notion that California law provides "an explicit, well-defined, and dominant public policy barring all contractual waivers of California workers' compensation." ${ }^{48}$ Instead, the court announced a "nuanced analysis in which courts considered the extent of California's interest in providing workers' compensation." ${ }^{49}$ Thus, the attempt to contractually foreclose the employee from workers' compensation benefits in Alaska Packers' was not automatically rendered contra public policy and void as a matter of law. Rather, the limiting contractual provision was held void and unenforceable as against public policy only after a factual determination by the court that California had a sufficiently weighty interest in providing workers' compensation in that particular instance. Specifically, the court noted that California had a legitimate and tangible public policy interest in providing workers' compensation benefits to the employee in Alaska Packers' because the employment contract at issue was created in California. ${ }^{50}$

In Matthews, no such interest existed because Matthews did not sign his contract in California, played only a limited number of games in California during his nineteen year career, did not allege that he sustained any particular injury in California or needed medical services in California, or put any burden on the state's resources, and

quotation marks omitted); Aramark Facility Servs. v. Serv. Emps. Int'l Union, Local 1877, AFL CIO, 530 F.3d 817, 823 (9th Cir. 2008) ("Arbitration awards are ordinarily upheld so long as they represent a plausible interpretation of the contract.") (internal quotation marks omitted).

47 Matthews, 688 F.3d at 1111 (internal quotation marks omitted).

48 Nat'l Football League Players Ass'n v. Nat'l Football League Mgmt. Council, No. 10CV1671 JLS WMC, 2011 WL 31068, at*5 (S.D. Cal. Jan. 5, 2011).

49 Id.

50 Alaska Packers' Ass'n v. Indus. Accident Comm'n of Cal., 294 U.S. 532, 542-43 (1935); Alaska Packers' Ass'n v. Indus. Accident Comm'n of Cal., 34 P.2d 716, 720 (1934) (noting California's legislative directive that the workers' compensation statute "shall apply to injuries received abroad where the contract of hire is made within the state"). See also Pac. Emp'rs Ins. Co. v. Indus. Accident Comm'n, 75 P.2d 1058, 1062 (Cal. 1938) (concluding that an employee who lived in Massachusetts, signed an employment contract in Massachusetts, and worked primarily in Massachusetts, but was injured while temporarily working in California, could not recover California workers' compensation benefits if Massachusetts' interests in the matter were greater than California's interests).

51 Interestingly, counsel for Matthews did not even allege in his complaint that he played any games in California. Instead, the court took judicial notice of the fact that Matthews' teams played thirteen games in California during his career. Matthews, 688 F.3d at 1113. 
only asserted that he "suffered cumulative injuries ... at various' locations between 1983 and 2001.,"52

The lack of contacts with California, in conjunction with the narrow standard of review, was fatal to Matthews' case. After all, the court was not asked to determine whether Matthews' situation presented California with a sufficiently weighty interest in providing workers' compensation such that the choice of law clause would be voided as against public policy. That is, the court was not asked to determine if Matthews was eligible for workers' compensation in California. Rather, because the court was reviewing an arbitration award, it was "charged with determining only whether there is an explicit, well-defined, dominant public policy militating against the arbitration award." Given that California's public policy in these cases is situation-specific (varying with the strength of California's interest in the particular case), the district court held that there could not be a "dominant" or "blanket" public policy sufficient to overturn the arbitration award. ${ }^{54}$ Because contractual provisions can override employees' California workers' compensation rights in some cases, the court was unwilling to recognize the existence of a dominant public policy favoring the award of benefits in cumulative injury cases worthy of overturning the Matthews arbitration.

The Ninth Circuit affirmed using a slightly different analysis and essentially announced an "eligibility plus" standard. Given Matthews' lack of contacts with the state, the court concluded that it was not clear that he was entitled to benefits under California's workers' compensation laws. ${ }^{55}$ According to the court, "[ $\left.\mathrm{t}\right]$ he facts underlying Matthews' claim are distinct enough from existing California cases that we cannot say whether the California courts would consider Matthews' limited contacts with the state sufficient to justify the application of California law." ${ }^{56}$ Matthews alleged that he was injured in California because all of the games he played during his career-some of which

52 Matthews, 688 F.3d at 1113. Similarly, in Haynes, the district court noted that the Bears players' contracts were signed and substantially performed in Illinois, the Bears are located in Illinois, the parties negotiated for exclusive Illinois choice-of-law and choice-of-forum provisions, none of the players alleged that they had sustained any particular injury in California, and the players had only played approximately three percent of their games in California. Given the lack of contact with California, the court not only found that California had no "dominant" public policy that would override the choice of law/forum provisions, but also asked "why is California's public policy relevant at all?" Similar facts and conclusions doomed the players' cases against the Falcons, Chiefs, and Saints. Chicago Bears Football Club, Inc. v. Haynes, 816 F. Supp. 2d 534, 538 (N.D. Ill. 2011).

53 Matthews, 688 F.3d at 1111,1114-15 (internal quotation marks omitted).

54 Id.

55 Id. at $1113-14$.

56 Id. at 1114. 
took place in California-contributed to his cumulative injuries. ${ }^{57}$ Although the court conceded, as a matter of fact, that all of Matthews' games-including the ones in California-may have contributed to his cumulative trauma, "it is not clear that, as a matter of California law, this means he falls within the category of employees to whom California extends workers' compensation coverage." cause of the limited precedent in the area, the Ninth Circuit could not determine with certainty that Matthews was entitled to workers' compensation benefits as a matter of law and thus could not conclude that the "arbitration award is contrary to a clear, well-defined and dominant public policy of the state of California." gested that a player facing an adverse arbitration award must not only allege that he is eligible for benefits under California's regime, but that he is "eligible plus." That is, the player must allege facts that make it clear that he is covered under California's policy.

The Ninth Circuit made it clear, however, that it was not holding that employers could use choice of law/forum clauses to trump employees' rights to seek California workers' compensation benefits in all cases. ${ }^{60}$ Rather, the Ninth Circuit noted that an employee who can make a prima facie showing that his injury would be covered under California's workers' compensation regime may be able to show that a contractual provision prohibiting him from seeking benefits in California $^{61}$ violates public policy and is therefore unenforceable. ${ }^{62}$ Matthews failed to make such a prima facie case because, according to the Ninth Circuit, he failed to allege that he suffered a specific injury in California or placed any burden on the state's medical system and because it was not "clear that California would extend its workers' compensation regime to cover the cumulative injuries" given Matthews' limited contact with the state.

Again, it is important to note that the Ninth Circuit was not deciding in the first instance if Matthews was eligible under California law for workers' compensation benefits for his cumulative injuries suffered (allegedly) in part while playing in California. Rather, the Ninth Circuit held only that it needed a clearer showing of Matthews'

\footnotetext{
$I d$.

$I d$.

$I d$.

Id. ("To be precise, we do not hold that employers may use binding arbitration of choice of law clauses as a means to evade California law where it would otherwise apply.").

61 Or, more specifically, an arbitration award upholding such a contractual provision.

62 Matthews, 688 F.3d at 1112, 1114.

63 Id. at $1115-16$.
} 
entitlement to California benefits because it was required to give great deference to the arbitration award denying Matthews' benefits. ${ }^{64}$

The Ninth Circuit's decision was thus a loss for Matthews but at least a partial victory for other players seeking benefits from California's workers' compensation system. After all, the court's decision seems to suggest that an employer can contract around an employee's California workers' compensation benefits only if it is not clear that the employee is otherwise entitled to California workers' compensation benefits. ${ }^{65}$ In other words, the Titans were able to contractually preclude Matthews from seeking workers' compensation benefits in California for his cumulative injuries because Matthews' lack of contacts with California raised at least some question about his eligibility for workers' compensation benefits in California. ${ }^{66}$ More significantly, however, the Ninth Circuit's opinion suggests such contractual waivers would be voided as contra public policy if the employee were clearly entitled to benefits in California. Matthews would have been able to override the contractual waiver if he had been able to allege that he suffered an injury in California, placed a burden on California's medical system, or had some other more significant contact with the state other than merely playing a fraction of his NFL games there. The Ninth Circuit, however, was unwilling to vacate the arbitration award given the lack of clarity regarding Matthews' eligibility for California benefits and thus the lack of clarity regarding the strength of California's public policy interests.

This decision closed the door on Matthews but leaves the door open for players who can allege sufficient contacts with California to indicate that California has a "dominant" or "clear" public policy in ensuring such player receives workers' compensation benefits in the state. Where that line will be drawn is unclear, but Matthews provides a rough road map for players, and we can expect to see players filing complaints that more specifically tie their injuries to California where possible. That line may also become clearer if California hands down more decisions indicating the strength or weakness of California's public policy in granting benefits for cumulative trauma where no specific injury in California is alleged.

For now, however, as both the district court and Ninth Circuit opinions suggest, it is not enough for players to show that they would otherwise have been eligible for benefits in California because of the

64 Id.

65 See id. at 1116-17.

66 Obviously, in cases where the employee is not entitled to benefits in California, a waiver of those benefits is unnecessary.

67 Matthews, 688 F.3d at 1116-17. 
cumulative trauma they suffered while playing at least one game in California. Rather, players must allege "eligibility plus" to show that California has a clear or dominant interest in providing benefits to them. Without such a showing, the Ninth Circuit is unwilling to void a contractual provision restricting players from seeking benefits outside of their respective home teams' states.

Thus, while the NFL has won most of the early battles to carve away California's broad jurisdiction through choice of law/forum provisions, the fight will continue as courts struggle with California's interest in protecting players who may have suffered cumulative injuries while playing a limited number of games in the state. The battle also continues over the interpretation of the reciprocity provision the California system.

\section{RECIPROCITY}

While the teams and players will continue to battle over the efficacy of the choice of law/forum provisions in players' contracts, the "reciprocity measure" in California's workers' compensation regime has served as another avenue for teams to seek relief from claims in California. $^{68}$ Although California's workers' compensation regime provides protection and benefits for all in-state injuries (including cumulative trauma), the reciprocity carve-out in Section 3600.5(b)

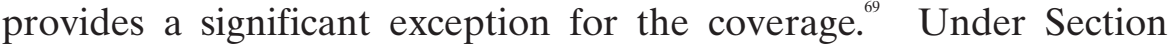
3600.5(b), an employer is exempt from California's workers' compensation scheme if all of the following conditions are met:

68 CAL. LAB. CODE $§ 3600.5$ (b) (2012). The statute states as follows:

(b) Any employee who has been hired outside of this state and his employer shall be exempted from the provisions of this division while such employee is temporarily within this state doing work for his employer if such employer has furnished workmen's compensation insurance coverage under the workmen's compensation insurance or similar laws of a state other than California, so as to cover such employee's employment while in this state; provided, the extraterritorial provisions of this division are recognized in such other state and provided employers and employees who are covered in this state are likewise exempted from the application of the workmen's compensation insurance or similar laws of such other state. The benefits under the Workmen's Compensation Insurance Act or similar laws of such other state, or other remedies under such act or such laws, shall be the exclusive remedy against such employer for any injury, whether resulting in death or not, received by such employee while working for such employer in this state.

A certificate from the duly authorized officer of the appeals board or similar department of another state certifying that the employer of such other state is insured therein and has provided extraterritorial coverage insuring his employees while working within this state shall be prima facie evidence that such employer carries such workmen's compensation insurance.

Id.

69 Id. 
1)The employer has provided workers' compensation insurance of a similar nature in another state;

2)California's extra-territorial provisions are recognized in that other state;

3)California's employees are afforded a reciprocal exemption under the law of the other state; fornia.

4)The employee was "temporarily" performing work within Cali-

The challenge for teams seeking to gain an exemption via the reciprocity measure is proving that the employee was "temporarily" working in California. There is little precedent in this area, but the early decisions of the California Workers' Compensation Board are split. In Carroll, the Board held that Carroll's relatively minimal time spent playing football in California was sufficient to constitute "regular" (and thus not temporary) employment for purposes of the reciprocity provision." The Board noted that "the Bengals are a part of the NFL and its games are scheduled in California in a deliberate and regular manner in the course of their business of playing professional football games." ${ }^{, 2}$ The Board conceded that Carroll's employment activity was "very minor, time-wise," but concluded that the NFL's decision to regularly schedule games in California was sufficient to render an NFL player who plays a single game in California as "regularly employed" within the state. . $^{73}$ This classification thus eliminates a league's ability to utilize the reciprocity provision to exempt their players from coverage under California's workers' compensation regime.

In Booker v. Cincinnati Bengals, the Board reached the opposite conclusion under a similar factual scenario. ${ }^{74}$ The Board found that Booker, who had played one game in California during his three seasons with the Cincinnati Bengals, was not "regularly" employed in California and therefore found him to be a "temporary employee" for purposes of the reciprocity measure. ${ }^{75}$ The Board found that the other prongs of California Labor Code $\S 3500.5(\mathrm{~b})$ were met and therefore

$70 \quad$ Id. Other states have similar reciprocity measures. See, e.g., OHIO REV. CODE $\S 4123.54$ (2012); NEV. REV. STAT. § 616.344 (2012); R.I. GEN. LAWS § 28-29-15 (2012); UTAH CODE. § 35-155 (2012).

71 Carroll v. New Orleans Saints, No. ADJ2295331 (ANA0397551), at 11-14 (Workers' Comp. Appeals Bd. Jan. 24, 2011).

72 Id. at 14.

73 Id. at 13-14.

74 Booker v. Cincinnati Bengals, No. ANA 0401410, at 2, 10-11 (Cal. Workers' Comp. App. Bd. Feb. 8, 2012).

75 Id. 
concluded that Booker was required to pursue his workers' compensation claims in Ohio.

Both conclusions contain some merit. To the extent that the focus is on the relative length of time spent in California, players from non-California teams may best be deemed "temporarily" employed in California. To the extent that the focus is on the fact that all teams regularly play football in California, players from non-California teams may best be deemed "regularly" employed in California. A full discussion of the merits of these arguments is well beyond the scope of this brief essay, but the reciprocity provision may turn out to be the best avenue for non-California teams to shut the door on California, particularly where the former players are able to allege a specific injury in California.

\section{CONCLUSION}

While the massive multi-district concussion litigation between retired NFL players and the NFL steals most of the headlines, the battle over workers' compensation rights between former players and their NFL teams is quietly working its way through the courts. Teams have had early success closing the door on California workers' compensation benefits through the use of choice of law/forum clauses, but the recent Matthews decision paints a road map for former players-or the state of California-to pry the door back open. 